\title{
PENERAPAN SISTEM PEMASARAN BERBASIS ONLINE PADA PRODUK BADAN USAHA MILIK DESA (BUMDES) "USAHA BERSAMA" DESA SEBAYAN KABUPATEN SAMBAS
}

\author{
Heldi Hastriyandi ${ }^{(1)}$, Munandar ${ }^{(2)}$ \\ Politeknik Negeri Sambas, Jln Sejangkung Kawasan Pendidikan, Sambas 79400, Indonesia ${ }^{(1)}$ \\ Politeknik Negeri Sambas, Jln Sejangkung Kawasan Pendidikan, Sambas 79400, Indonesia ${ }^{(2)}$ \\ Heldi.poltesa@gmail.com
}

\begin{abstract}
ABSTRAK
Pembentukan Badan Usaha Milik Desa (BUMDES) merupakan sebuah langkah maju yang dilakukan oleh perangkat desa dalam rangka meningkatkan pendayagunaan segala potensi ekonomi, kelembagaan ekonomi, serta potensi sumber daya alam dan sumber daya manusia untuk meningkatkan kesejahteraan masyarakat desa. Pada perkembangannya, dengan dikeluarkannya regulasi yang mendukung UU Desa, yaitu PP No. 60/2014 tentang Dana Desa. Peraturan ini mengatur bahwa desa yang sekarang sudah bisa aktif turut membangun, perlu disokong dengan dana. Artinya, dana desa diadakan dengan dua cita-cita: pemerintah desa lebih bisa sanggup melayani kebutuhan warga, sekaligus warganya lebih aktif berinisiatif. Salah satu wadah untuk memajukan ekonomi desa adalah melalui Badan Usaha Milik Desa atau BUMDes. Desa Sebayan merupakan Desa Administrasi dari 18 Desa dalam wilayah Kecamatan Sambas yang berjarak 8 Km dari Ibu Kota Sambas Saat ini desa Sebayan telah membentuk BUMDes guna menampung serta menjual produk - produk berupa pupuk, bibit serta obat-obatan pembasmi hama dengan membuka toko. Selama ini produk - produk tersebut masih dipasarkan atau dijual hanya pada lingkup warga sekitar (lokal), padahal dengan perkembangan teknologi yang semakin meningkat sekarang ini sistem penjualan pada BUMDes sudah seharusnya menggunakan sistem penjualan berbasis online. Dengan adanya sistem penjualan online diharapkan dapat memperluas segmen pemasaran produk BUMDes tidak hanya bersifat lokal, namun meningkat hingga antar desa, kecamatan, kabupaten bahkan ke level nasional dan internasional. Keberhasilan BUMDes tidak hanya pada jumlah produk yang ditawarkan, namun juga bergantung pada perangkat atau sember daya manusia dalam melakukan manajemen pengelolaan BUMDes itu sendiri. Kendala yang dihadapi saat ini adalah lemahnya pengetahuan dan kemampuan pengelola BUMDes dalam hal pemamfaatan Teknologi Informasi (TI) dalam melakukan pemasaran dan penjualan secara online atau yang dikenal dengan istilah e-commerce. Tujuan pengabdian masyarakat ini adalah ingin memberikan pengetahuan dan keterampilan kepada perangkat pengelola BUMDes "Usaha Bersama" desa Sebayan melalui pemanfaatan teknologi e-commerce guna memperluas pemasaran penjual produk.
\end{abstract}

Kata Kunci : Pemasaran, BUMDes, E-Commerce, Desa Sebayan, Media Online

\begin{abstract}
The establishment of a Village-Owned Enterprise (BUMDES) is a step forward by the village apparatus in order to improve the utilization of all economic potential, economic institutions, as well as the potential of natural resources and human resources to improve the welfare of rural communities. In its development, with the issuance of regulations supporting the Village Law, namely PP No. 60/2014 concerning Village Funds. This regulation stipulates that villages that can now actively participate in building, need to be supported by funds. That is, village funds are held with two ideals: the village government is better able to serve the needs of citizens, as well as its citizens are more active in taking the initiative. One of the ways to advance the village economy is through Village Owned Enterprises or BUMDes. Sebayan Village is an Administrative Village of 18 Villages in the Sambas District area which is $8 \mathrm{Km}$ from the capital city of Sambas. Currently the village of Sebayan has formed BUMDes to accommodate and sell products in the form of fertilizers, seeds and pest exterminating drugs by opening a shop. So far, these products are still
\end{abstract}


marketed or sold only to the surrounding (local) citizens, whereas with the increasing technological development nowadays the sales system at BUMDes is supposed to use an onlinebased sales system. The existence of an online sales system is expected to expand the marketing segment of BUMDes products not only locally, but increasing to between villages, sub-districts, districts and even to national and international levels. BUMDes' success is not only in the number of products offered, but also depends on the device or human resources in managing the management of BUMDes itself. The constraints faced today are the lack of knowledge and ability of BUMDes managers in terms of the use of Information Technology (IT) in conducting online marketing and sales or what is known as e-commerce. The purpose of this community service is to provide knowledge and skills to the management devices of the BUMDes "Usaha Bersama" Sebayan village through the use of e-commerce technology to expand the marketing of product sellers.

Keywords: Marketing, BUMDes, E-Commerce, Sebayan Village, Online Media

\section{PENDAHULUAN}

\subsection{Analisis Situasi}

Perkembangan bisnis online telah merambah dikalangan masyarakat seiring dengan perkembangan teknologi, komunkasi, komputer serta gadged. Hal ini secara langsung telah berpengaruh terhadap pertumbuhan ekonomi masyarakat. Bisnis online saat ini merupakan sebuah peluang yang sangat menjanjikan untuk dikembangkan, terlebih lagi dengan perkembangan perangkat komunikasi yang sekarang marak yaitu perangkat smartphone berbasis android yang mudah didapat dengan harga yang relatif murah. Melalui perangkat ini membuat setiap orang dapat terhubung satu dengan lainnya lewat media internet, sehingga bisnis online semakin mudah untuk dilakukan dimana calon pembeli dengan mudah mencari barang yang diinginkan serta penjual juga dengan mudah mempromosikan atau memasarkan hasil produk mereka.

Desa Sebayan merupakan Desa Adm inistrasi dari 18 Desa dalam wilayah Kecamatan Sambas yang berjarak $10 \mathrm{Km}$ dari Ibu Kota Sambas. Desa Sebayan merupakan salah satudesa yang sudah menjalankan roda ekonomi kerakyatan yaitu melalui pembentukan BUMDes dan sudah berjalan hingga saat ini. BUMDes
"Usaha Bersama"desa Sebayan sudah melakukan bisnis di bidang pertanian berupa penjualan produk pupuk, bibit, serta obat-obatan pembasmi hama tanaman dan beberapa hasil pertanian masyarakat. Saat ini penjualan masih dilakukan secara manual dari mulut ke mulut, sehingga pemasaran produk masih pada tataran warga sekitar saja atau bersifat lokal. Pemanfaatan TI khususnya e-commerce dalam memperluas pangsa pasar masih belum dilakukan secara optimal dimana hal ini merupakan kesempatan dan peluang yang seharusnya sudah dapat dilakukan dengan perkembangan teknologi yang semakin pesat. Dalam pemamfaatan teknologi tidak hanya fokus kepada produk yang akan dipasarkan, namun juga harus difokuskan pada peningkatan skil Sumber daya manusia dalam hal ini adalah perangkat BUMDes dalam hal memanfaatkan Teknologi Informasi(TI) dalam melakukan pemasaran dan penjualan secara online atau yang dikenal dengan istilah e-commerce.

Dengan memanfaatkan $e-$ commerce promosi dan penjualan produk BUMDes pada khususnya dapat dilakukan keseluruh dunia tanpa batasan waktu dan dengan biaya yang sangat rendah daripada promosi secara konvensional 
sehingga penawaran produk/jasa dapat dilakukan kapan saja dan dimana saja.Salah satu juga keunggulan desa Sebayan kabupaten Sambas pada umumnya memiliki letak geografis yang cukup strategis dari segi ekonomi yaitu berbatasan dengan wilayah negara tetangga yaitu Malaysia sebenarnya menjadi potensi bagi pemasaran produk BUMDes.

Tujuan pengabdian masyarakat ini adalah untuk memberikan pelatihan pemasaran produk dan pemamfaatan Teknologi Informasi guna memperluas promosi dan pemasaran produk-produk BUMDes sehingga lebih dikenal oleh masyarakat secara luas (global) serta meningkatkan pengetahuan dan keterampilan (skill) pengelola BUMDes dalam melakukan manajemen bisnis sehingga dapatmeningkatkan pendapatan BUMDes dan mensejahterakan masyarakat pada umumnya.

\subsection{Permasalahan Mitra}

Berdasarkan hasil observasi yang telah dilakukan diketahui bahwapemasaran produk BUMDes saat ini masih dilakukan secara manual dari mulut ke mulut dimana penjualan hanya mencakup warga sekitar (lokal), sehingga pendapatan BUMDes dinilai belum optimal.Padahal untuk peluang customer segment, produk BUMDes ini diharapkan dapat membantu masyarakat di kabupaten Sambas pada umumnya bahkan secara global. BUMDes "Usaha Bersama"DesaSebayan sangat ingin sekali memasarkan dan mempromosikan langsung produk BUMDes menggunakan media penjualan berbasis online sehingga diharapkan dapat meningkatkan omzet penjualan dan menggerakan ekonomi kerakyatan yang nantinya tidak hanya pada bidang pertanian namun hingga merambah ke bidang lainnya seperti kerajinan tangan.

\section{SOLUSI DAN TARGET LUARAN \\ 2.1. SOLUSI}

Solusi yang ditawarkan dalam kegiatan ini adalah memberikan tambahan pengetahuandan ketrampilan kepada perangkat BUMDes Desa Sebayan berupa pelatihan, ceramah dan diskusi mengenai penerapan aplikasi EComerce. Solusi dari kegiatan ini adalah :

1. Dengan menggunakan ECommerce, BUMDes dapat memperluas pemasaran produk ke pasar nasional bahkan internasional serta dapat dengan mudah menemukan lebih banyak pelanggan, pemasok terbaik dan mitra bisnis.

2. Dengan menggunakan ECommerce telah memungkinkan akses terhadap layanan dan produk bagi masyarakat secara luas.

3. Dengan menggunakan ECommerce dapat meningkatkan produktivitas BUMDes dalam menjalankan bisnis.

Target luaran dari pengabdian masyarakat ini adalah :

1. Meningkatkanpengetahuanmitrat entangmodel pemasaran

2. Meningkatkan pengetahuan mitra tentangpromosi dan penjualan produk menggunakan gerai online.

3. Melakukan transfer teknologi kepada mitra tentang pemanfaatan media internet sebagai media promosi sekaligus media pemasaran produk mitra. 


\section{METODOLOGI}

Kegiatan ini dilakukan dengan metode sebagai berikut :

1. Pemaparan Model Pemasaran Pada bagian ini, pelaksana pengabdian mengadakan penyampaian materi (teori) mengenai model pemasaran guna memberikan wawasan kepada pesertadalam mendukung usaha mereka.

2. Pemaparan Manfaat Media Internet

Pada bagian ini, pelaksana pengabdian mengadakan pelatihan mengenai pentingnya pemanfaatan media internet dalam mendukung usaha mereka. Pemaparan mengenai pemamfaatan media internet sebagai media iklan bisnis, katalog produk yang dapat dilakukan secara gratis serta dampak positif dan negatif dari internet.

3. Pengenalan Aneka Gerai Online

Pelatihan pengenalan gerai online bertujuan untuk memberikan informasi bahwa mitra juga dapat menjual produknya melalui gerai online yang ada di Indonesia. Pada pelatihan ini mitra diinformasikan cara untuk regristrasi dan melakukan transaksi pada beberapa gerai online.

4. Penerapan E-commerce

Pada bagian ini pelaksana pengabdian kepada masyarakat mengenalkan aplikasi pemasaran berbasis web yang dapat digunakan oleh mitra dalam melakukan penjualan produknya secara online.

5. Pemaparan Proses Paket Pengiriman Barang

Pada bagian ini, pelaksana pengabdian mengadakan penyampaian materi mengenai Standart dalam melakukan paket pengiriman barang

\section{HASIL DAN PEMBAHASAN}

Dengan adanya pelatihan ini telah memberikan pengetahuan dan menambah ilmu terutama berkaitan dengan komputer dan system pemasaran berbasis online kepada staf BUMDES "Usaha Bersama" Desa Sebayan Kabupaten Sambas. Adapun dokumentasi kegiatan tersebut sebagai berikut :

1. Kegiatan Pemaparan Model

Pemasaran

Pada kegiatan PKM ini didahului dengan pemaparan mengenai model - model pemasaran serta dibahas secara rinci mengenai model pemasaran secara online.

Adapun dokumentasi kegiatan ini dapat dilihat pada gambar 1

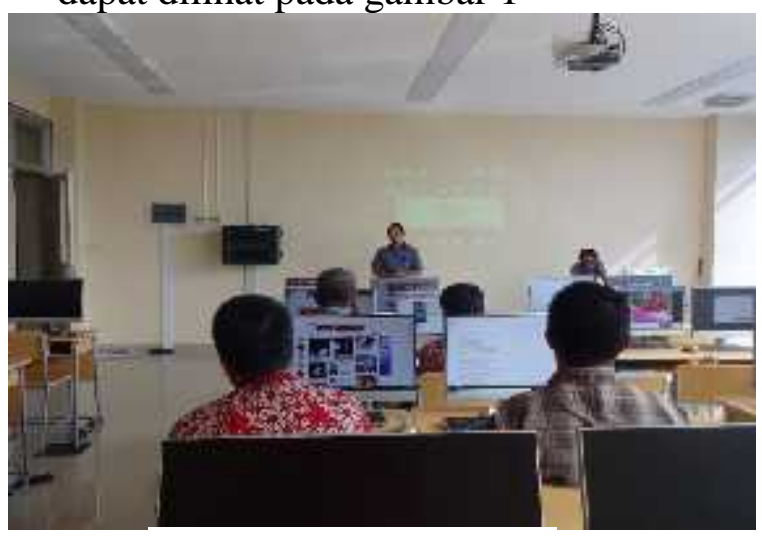

Gambar 1. Dokumentasi

Pemaparan Model Pemasaran

\section{Pemaparan Mamfaat media} Internet

Pada sesi ini peserta diberikan pemaparan materi mengenai perkembangan teknologi, terutama 
internet, selain itu juga diberikan praktek pengenalan beberapa browser popular seperti mozila firefox dan google chrome. Pada kegiatan PKM ini melibatkan 2 orang mahasiswa program studi manajemen informatika politeknik negeri Sambas guna membantu peserta yang masih awam baik dalam menggunakan komputer maupun internet. Adapun dokumentasi kegiatan ini dapat dilihat pada gambar 2 dan 3 .

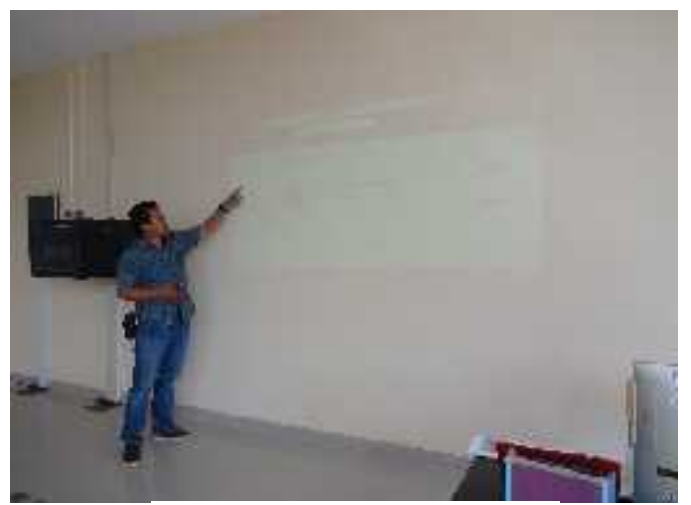

Gambar 2. Dokumentasi Pemaparan Mamfaat Media Internet

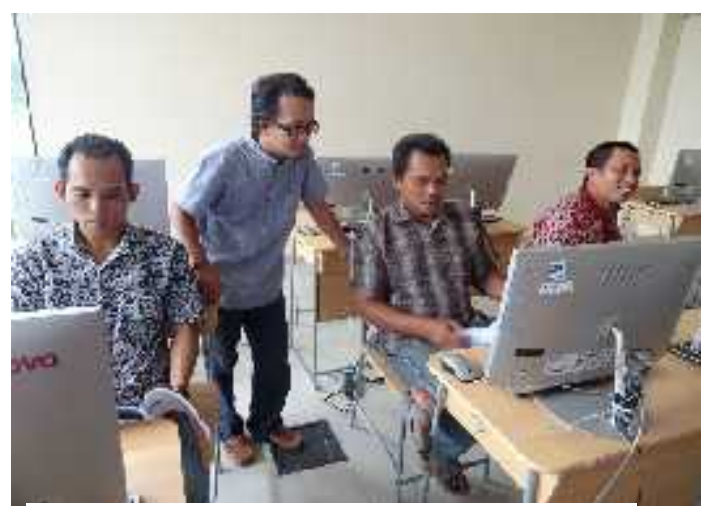

Gambar 3. Dokumentasi Pengenalan Browser Mozila dan Google Chrome pada peserta

\section{Pengenalan Aneka Gerai Online.}

Untuk meningkat pendapatan BUMDES selain menggunakan informasi dari mulut ke mulut, juga terdapat cara yang juga efektif dan efisien yaitu menggunakan media pemasaran online yang sangat popular saat ini. Pada Sesi ini user diperkenalkan dan mempraktekkan pembuatan user akun pada beberapa situs penjualan online diantaranya Bukalapak, Tokopedia, dan Shopee.

\section{Penerapan E-commerce}

Selain mengenalkan beberapa gerai online peserta juga dibimbing untuk menginputkan data barang produk yang terdapat pada BUMDES berupa foto produk ,jumlah harga, jumlah stok, serta cara pencairan dana via Bank sesuai dengan situs penjualan online (gerai online) yang diakses. Adapun Dokumentasi kegiatan ini dapat dilihat pada gambar 4 dan 5.

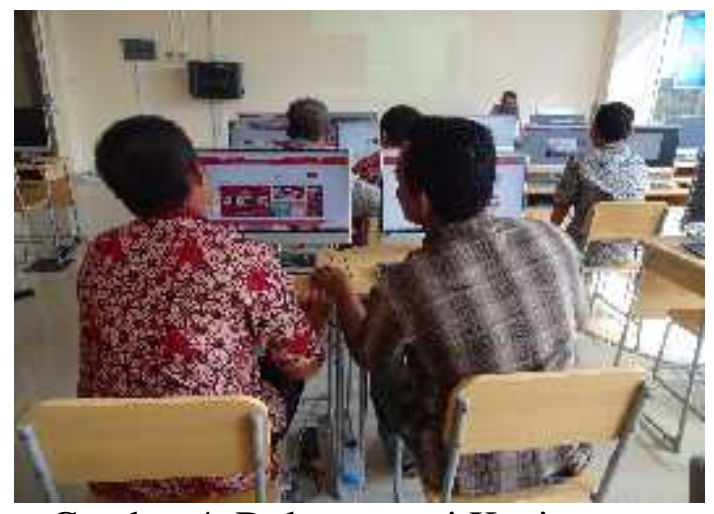

Gambar 4. Dokumentasi Kegiatan Praktek Pembuatan Akun oleh peserta

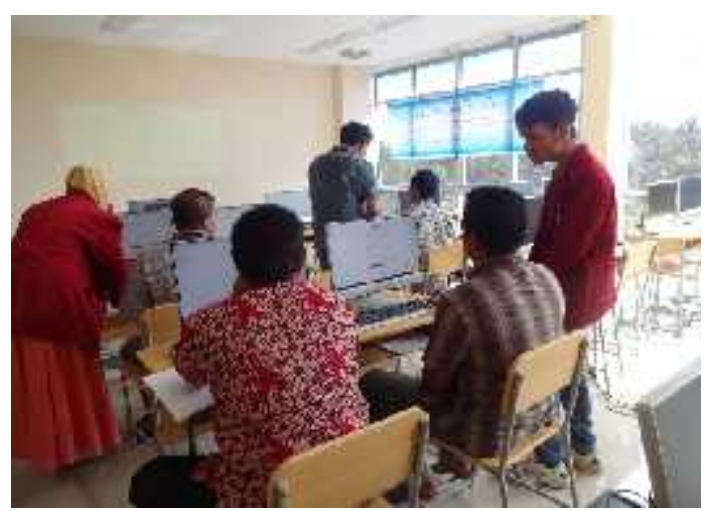

Gambar 5. Dokumentasi Kegiatan Penginputan Data Produk Bumdes oleh Peserta 
5. Pemaparan Proses Paket Pengiriman Barang.

Rangkaian akhir dari kegiatan PKM ini adalah dengan memperkenalkan dan membangun hubungan antara pihak BUMDES dan perusahaan jasa pengiriman barang. Hal ini dilakukan untuk memperlancar proses pengiriman terutama pengiriman dangan fitur ambil ditempat, dimana BUMDES tidak perlu lagi mengantar paket barang ke kantor jasa pengiriman namun sudah dipermudah dengan sistem penjemputan paket oleh pihak jasa ekspedisi. Untuk mengetahui standar operasional prosedur dalam pengiriman paket barang, pada kegiatan ini peserta juga diberikan materi mengenai SOP system pemaketan barang oleh salah satu perusahaan jasa pengirman barang. Adapun dokumentasi kegiatan ini dapat dilihat pada gambar 6 .

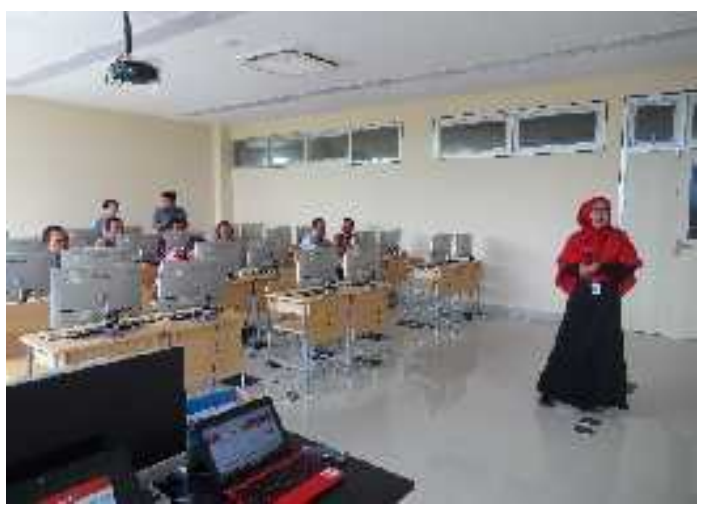

Gambar 6. Pemaparan SOP

Pengiriman Paket Barang

\section{Kesimpulan Dan Saran}

\subsection{Kesimpulan}

Adanya pelatihan Penerapan Sistem Pemasaran Berbasis Online PadaProdukBadan Usaha Milik Desa (BUMDes) "Usaha Bersama"diDesa Sebayan Kecamatan Sambasdapat memberi manfaat yang sangat besar tentang bagaimana melakukan manajemen guna meningkatkan pendapatan dari hasil pemasaran serta produk - produk BUMDES “ Usaha bersama " lebih dikenal oleh masyarakat tidak hanya lokal namun hingga ke tingkat nasional bahkan international. Dengan adanya pelatihan ini peserta pelatihan dapat dengan mudah memasarkan dan menjual produk Bumdes dengan menggunakan teknologi berbasis online, bahkan dapat menjalin kerjasama dengan perusahaan yang bergerak di bidang pengiriman barang sehingga biaya jasa pengiriman dapat ditekan lebih murah.

\subsection{Saran}

Untuk menggunakan Aplikasi berbasis e-commerce, diperlukan peningkatan kegiatan bimbingan dan monitoring sehingga kendala kendala yang dihadapi oleh anggota Bumdes "Usaha Bersama" terutama dalam bidang teknologi dapat diatasi secara bersama- sama. Kegiatan ini nantinya dapat dilanjutkan hingga pada proses pengemasan (packaging) produk bumdes sehingga menarik minat komsumen.

\section{UCAPAN TERIMA KASIH}

Ucapan terima kasih disampaikan kepada P3M Politeknik Negeri Sambas (Poltesa) yang telah membiayai kegiatan penelitian ini melalui Program Penelitian dan PKM internal Politeknik Negeri Sambas.

\section{DAFTAR PUSTAKA}

Ahmadi, C. dan Hermawan, D. (2014), E-business dan Ecommerce, Andi Offset, Yogyakarta.

Irnawati, Dewi, , "Pemanfaatan ECommerce Dalam Dunia 
Bisnis,Jurnal Ilmiah Orasi Bisnis, Edisi Ke-VI, November 2011.

Madncoms, (2011), Sukses Membangun Toko Online dengan E-commerce, Andi Offset, Yogyakarta.

Purbo, O. W dan Daniel, S., (2000), Membangun Web E-Commerce, Elex Media Komputindo

Waloeyo (2012), Cloud Computing, Andi Offset, Yogyakarta.

E-commerce: business. technology. society., 2/E: Kenneth C. Laudon, New York University: Jeffrey Travis,Nacimiento Software Corporation, Austin, Texas 